\title{
GABAergic Control of Adult Hippocampal Neurogenesis in Relation to Behavior Indicative of Trait Anxiety and Depression States
}

\author{
John C. Earnheart, ${ }^{1}$ Claude Schweizer, ${ }^{1}$ Florence Crestani, ${ }^{3}$ Takuji Iwasato ${ }^{4}$ Shigeyoshi Itohara, ${ }^{4}$ Hanns Mohler, ${ }^{3}$ and \\ Bernhard Lüscher ${ }^{1,2}$ \\ ${ }^{1}$ Departments of Biology and Biochemistry and Molecular Biology and Penn State Neuroscience Institute, Penn State University, University Park, \\ Pennsylvania 16802, ${ }^{2}$ Department of Psychiatry, Penn State College of Medicine, Hershey, Pennsylvania 17033, ${ }^{3}$ Institute of Pharmacology and Toxicology, \\ University of Zurich and Swiss Federal Institute of Technology Zurich, 8092 Zurich, Switzerland, ${ }^{4}$ Laboratory for Behavioral Genetics, RIKEN Brain Science \\ Institute, Wako-shi, Saitama, 351-0198, Japan
}

Stressful experiences in early life are known risk factors for anxiety and depressive illnesses, and they inhibit hippocampal neurogenesis and the expression of $\mathrm{GABA}_{\mathrm{A}}$ receptors in adulthood. Conversely, deficits in GABAergic neurotransmission and reduced neurogenesis are implicated in the etiology of pathological anxiety and diverse mood disorders. Mice that are heterozygous for the $\gamma 2$ subunit of $\mathrm{GABA}_{\mathrm{A}}$ receptors exhibit a modest functional deficit in mainly postsynaptic $\mathrm{GABA}_{\mathrm{A}}$ receptors that is associated with a behavioral, cognitive, and pharmacological phenotype indicative of heightened trait anxiety. Here we used cell type-specific and developmentally controlled inactivation of the $\gamma 2$ subunit gene to further analyze the mechanism and brain substrate underlying this phenotype. Heterozygous deletion of the $\gamma 2$ subunit induced selectively in immature neurons of the embryonic and adult forebrain resulted in reduced adult hippocampal neurogenesis associated with heightened behavioral inhibition to naturally aversive situations, including stressful situations known to be sensitive to antidepressant drug treatment. Reduced adult hippocampal neurogenesis was associated with normal cell proliferation, indicating a selective vulnerability of postmitotic immature neurons to modest functional deficits in $\gamma 2$ subunit-containing $\mathrm{GABA}_{\mathrm{A}}$ receptors. In contrast, a comparable forebrain-specific $\mathrm{GABA}_{\mathrm{A}}$ receptor deficit induced selectively in mature neurons during adolescence lacked neurogenic and behavioral consequences. These results suggest that modestly reduced $\mathrm{GABA}_{\mathrm{A}}$ receptor function in immature neurons of the developing and adult brain can serve as a common molecular substrate for deficits in adult neurogenesis and behavior indicative of anxious and depressive-like mood states.

Key words: anxiety disorder; mood; conditional knock-out mice; brain development; mouse behavior; hippocampal neurogenesis; inhibitory synaptogenesis; Cre-loxP; depression; stress

\section{Introduction}

High trait anxiety is a vulnerability factor for diverse psychiatric conditions, especially generalized anxiety disorder (GAD) and major depression (Chambers et al., 2004). Furthermore, genetic factors and environmental stress, including early life stress, are implicated as vulnerability factors of anxiety and mood disorders (Chorpita and Barlow, 1998). Studies in animals indicate that early life stress results in deficits in adult neurogenesis (Mirescu et

\footnotetext{
Received Aug. 19, 2006; revised Feb. 18, 2007; accepted Feb. 24, 2007.

This work was supported by Whitehall Foundation Grants 1999-12-16-APL and National Institutes of Mental Health Grants MH62391 and MH60989 to B.L. We thank D. Diloreto, S. Lingenfelter, and M. Martin for technical assistance, Drs. Anne Andrews, Aimin Liu, and Randen Patterson for critical comments on this manuscript, and Dr. Doug Cavener for Z/EG mice.

Correspondence should be addressed to Dr. Bernhard Luscher, Departments of Biology, Biochemistry and Molecular Biology, and Psychiatry, 301 Life Sciences Building, Penn State University, University Park, PA 16802. E-mail: bxl25@psu.edu.

C. Schweizer's present address: Biologie Cellulaire de la Synapse Normale et Pathologique, Institut National de la Santé et de la Recherche Médicale, Unité 789, Ecole Normale Supérieure, 46 rue d'Ulm, 75005 Paris, France. DOI:10.1523/JNEUROSCI.3609-06.2007

Copyright $\odot 2007$ Society for Neuroscience $\quad$ 0270-6474/07/273845-10\$15.00/0
}

al., 2004; Karten et al., 2005), a phenomenon that has been further implicated in the etiology of depression (Duman, 2004). $\mathrm{GABA}_{\mathrm{A}}$ receptors $\left(\mathrm{GABA}_{\mathrm{A}} \mathrm{Rs}\right)$ are key control elements of anxiety states based on the anxiolytic properties of benzodiazepines (BZs), which act as allosteric GABA $\mathrm{A}$ agonists (Mohler et al., 2002; Kaplan and DuPont, 2005). Moreover, GABAergic deficits are implicated in the etiology of diverse mood disorders (Brambilla et al., 2003; Tunnicliff and Malatynska, 2003).

Structurally, $\mathrm{GABA}_{\mathrm{A}}$ Rs represent heteropentameric GABAgated chloride channels that are most commonly composed of different types of $\alpha$ and $\beta$ subunits, together with the $\gamma 2$ subunit. The $\gamma 2$ subunit of $\mathrm{GABA}_{\mathrm{A}} \mathrm{Rs}$ is essential for the formation of $94 \%$ of BZ binding sites (Gunther et al., 1995), normal GABA $\mathrm{A}_{\mathrm{A}} \mathrm{R}$ channel conductance (Gunther et al., 1995; Lorez et al., 2000), as well as trafficking and clustering of $\mathrm{GABA}_{\mathrm{A}} \mathrm{Rs}$ at postsynaptic sites (Essrich et al., 1998; Schweizer et al., 2003). Mice that are heterozygous for the $\gamma 2$ subunit $\left(\gamma 2^{+/-}\right)$exhibit modest but significant functional deficits in each of these parameters (Crestani et al., 1999). However, the number of $\mathrm{GABA}_{A} \mathrm{Rs}$ as judged by measurement of GABA binding sites is unaltered in these mutants. 
The $\gamma 2^{+/-}$mice have been characterized as an animal model of chronic or trait anxiety, as defined by Lister (1990), and they were shown to recapitulate emotional, behavioral, cognitive, and pharmacological features reminiscent of GAD (Crestani et al., 1999; McNaughton, 1999). In particular, $\gamma 2^{+/-}$mice exhibit increased risk assessment behavior and neophobia in a free-choice exploration paradigm that is devoid of intrinsic stress and marked behavioral avoidance to various other species-specific natural or learned stressors. This enhanced emotional behavior of $\gamma 2^{+1-}$ mice is normalized to wild-type (wt) levels by treatment with diazepam, thereby reproducing the increased sensitivity to BZs seen in anxious and neurotic patients (O'Boyte et al., 1986; Glue et al., 1995). Altered behavior of $\gamma 2^{+/-}$mice is associated with selective cognitive deficits, including enhanced $1 \mathrm{~s}$ trace conditioning and impaired ambiguous cue conditioning, but unaltered spatial memory (Crestani et al., 1999).

Here we used conditional Cre recombinase-induced inactivation of a "floxed" $\gamma 2$ subunit gene ( $f \gamma 2$ ) (Schweizer et al., 2003) to further characterize the cellular substrate of $\mathrm{GABA}_{\mathrm{A}} \mathrm{R}$ deficitassociated trait anxiety and behavioral inhibition. A modest deficit in $\gamma 2$ subunit-containing $\mathrm{GABA}_{\mathrm{A}}$ Rs induced in precursors of glutamatergic neurons of the embryo and extending to adult neural progenitor cells resulted in a pronounced deficit in adult hippocampal neurogenesis. The manifestation of this cellular phenotype was paralleled by neophobia and heightened inhibition in behavioral assays designed to assess anxiolytic and antidepressant drug activity, thereby qualifying $\gamma 2^{+/-}$mice as an animal model of negative emotionality (Gamez et al., 2006).

\section{Materials and Methods}

\section{Production and husbandry of mice}

All animal experiments were approved by the Institutional Animal Care and Use Committee of Pennsylvania State University and were performed in accordance with relevant guidelines and regulations. Mice that are heterozygous for the $\gamma 2$ subunit (global $\gamma 2^{+/-}$) and wild-type littermate controls were produced by crossings of $\gamma 2^{+/-}$and wt 129SvJ mice as described previously (Crestani et al., 1999). The $\gamma 2^{+/-}$mice have been backcrossed onto a 129 SvJ background for $>40$ generations. Conditional heterozygous knock-out mice and $\mathrm{f} \gamma 2 /+$ control littermates were generated by mating empty spiracles homolog 1 (Emx1)Cre (Iwasato et al., 2000) or calcium/calmodulin-dependent kinase (CaMKII)Cre2834 hemizygous mice with $\mathrm{f} \gamma 2 / \mathrm{f} \gamma 2$ or $\mathrm{f} \gamma 2 /+$ mice (Schweizer et al., 2003), all of which had been backcrossed into the 129SvJ background for at least six generations. Breeder mice were housed in standard shoebox cages with standard chow and water available ad libitum. Mouse litters for behavioral testing were produced one litter per large gang cage containing standard bedding supplemented with cloth nesting squares. To avoid early life stress induced by cage changes, the litters were left undisturbed without change of bedding until the day of weaning [postnatal day 21 (P21)], at which time they were genotyped by PCR analysis of tail biopsies (Gunther et al., 1995; Schweizer et al., 2003) and tagged with metal ear tags. Females destined for behavioral or neurogenesis testing were then separated by genotype and pooled into gang cages containing 8-12 animals per cage and transferred to a separate female-only holding room under a reversed light/dark cycle (dark from 12:00 P.M. to 12:00 A.M.). Genotypes were coded such that the experimenter doing the additional testing and data analyses was unaware of the genotype. The cages of behavioral test animals were changed once a week. Z/EG mice (Novak et al., 2000) were from The Jackson Laboratory (Bar Harbor, ME) and generously provided by Doug Cavener (Pennsylvania State University).

\section{Behavioral assessments}

Behavioral testing was performed at the age of $8-10$ weeks or $4-6$ months as indicated, at least $72 \mathrm{~h}$ after the last cage change and during the first $6 \mathrm{~h}$ of the dark phase. Comparisons between mutant and control mice represented comparisons between littermates, and each mouse was used in one test only, unless indicated otherwise. The behavior was vid- eotaped in the holding room under dim red light for subsequent off-line quantitation.

Free-choice exploration (Crestani et al., 1999). In a compartment containing six units $(10 \times 10 \times 20 \mathrm{~cm}$ each $)$, mice were placed individually into one segment comprising three interconnected units. After $24 \mathrm{~h}$ of familiarization, the remaining three novel units were made accessible, and the retractions from entering the novel segment, the number of visits, and the total time spent in familiar and novel units were recorded for $5 \mathrm{~min}$.

Light-dark choice (Crestani et al., 1999). In a chamber containing a dark and a lit box $(20 \times 20 \times 15 \mathrm{~cm})$ connected by a tunnel $(5 \times 8 \times 10$ $\mathrm{cm}$ ), mice were tested for $5 \mathrm{~min}$ after placement into the lit box (illumination, 700 lux). The total time spent in the lit area and the number of transitions between compartments were recorded.

Elevated plus maze (Crestani et al., 1999). On an elevated crossbar (30 $\mathrm{cm}$ per arm $\times 5 \mathrm{~cm}$ wide $\times 40 \mathrm{~cm}$ tall $)$ with two walled $(20 \mathrm{~cm}$, transparent) and two open arms, mutant mice and littermate controls were placed onto the center square and videotaped for $5 \mathrm{~min}$. The number of entries and the total time spent on closed and open arms were recorded.

Novelty-suppressed feeding test (Santarelli et al., 2003). Mice were deprived of food for $24 \mathrm{~h}$ preceding placement into the corner of a plastic box $(50 \times 50 \times 20 \mathrm{~cm})$ containing $3 \mathrm{~cm}$ of bedding and a pellet of food placed on a white paper platform $(8 \times 8 \times 0.5 \mathrm{~cm})$ in the center of the cage. Each test lasted $5 \mathrm{~min}$, and the measure of interest (chewing) was scored when the mouse was sitting on its haunches and biting with the use of its forepaws.

Modified forced swim test (Lucki, 1997). Mice tested in the noveltysuppressed feeding test were reused 1 week later. They were placed into a plastic bucket (19 $\mathrm{cm}$ in diameter and $27 \mathrm{~cm}$ deep) filled to $18 \mathrm{~cm}$ with $22-25^{\circ} \mathrm{C}$ water and videotaped for $6 \mathrm{~min}$. The real time spent swimming to the first floating episode and the cumulative time spent immobile during the final $4 \mathrm{~min}$, using a $5 \mathrm{~s}$ interval sampling method, were recorded.

Autoradiography of brain sections. Cryostat brain sections $(12 \mu \mathrm{m})$ used for autoradiography of BZ sites were mounted on poly-D-lysinecoated glass slides and probed with $5 \mathrm{~nm}\left[{ }^{3} \mathrm{H}\right]$ flumazenil as described previously (Gunther et al., 1995; Schweizer et al., 2003). The density of BZ binding sites was quantified in three sections per brain $(n=10-12$ brains per genotype) using a Cyclone storage phosphor imaging system with Optiquant software (PerkinElmer, Shelton, CT) and $\left[{ }^{3} \mathrm{H}\right] \mathrm{mi}-$ croscale autoradiography standards (Amersham Biosciences, Arlington Heights, IL).

Bromodeoxyuridine labeling and immunohistochemical analysis of adult-born neurons. Two different bromodeoxyuridine (BrdU) labeling protocols were used (1) to quantify adult-born hippocampal cells that had differentiated and assumed a mature neuronal phenotype as evidenced by expression of the neural marker neuronal-specific nuclear protein (NeuN) or (2) to quantify replicating cells as a measure of proliferation of undifferentiated neural progenitor cells. For quantitation of adult-born neurons that expressed NeuN, 8-week-old mice were injected with $\mathrm{BrdU}(4 \times 80 \mathrm{mg} / \mathrm{kg}$, i.p., at $2 \mathrm{~h}$ intervals, in saline at $8 \mathrm{mg} / \mathrm{ml}, \mathrm{pH}$ 7.4). The brains were harvested $28 \mathrm{~d}$ later, thereby allowing adult-born BrdU-labeled cells to differentiate into mature neurons. To quantify adult-born replicating/undifferentiated cells, 8-week-old mice were injected with a single dose of BrdU of $200 \mathrm{mg} / \mathrm{kg}(20 \mathrm{mg} / \mathrm{ml})$, and the brains were harvested $24 \mathrm{~h}$ later as above. The mice were anesthetized with ketamine/xylazine/acepromazine $(110,20$, and $3 \mathrm{mg} / \mathrm{kg}$, i.p., respectively) (Schein, Melville, NY), transcardially perfused with ice-cold PBS, followed by $4 \%$ paraformaldehyde in PBS, postfixed for $12 \mathrm{~h}$ in the same solution, and equilibrated in 30\% sucrose. Serial coronal sections (35 $\mu \mathrm{m})$ through the hippocampus were processed for immunofluorescent staining using mouse anti-NeuN (1:1000; Chemicon, Temecula, CA) and rat anti-BrdU monoclonal antibody (1:500; Accurate Chemical, Westbury, NY) and developed with FITC- and cyanine 3 (Cy3)-conjugated secondary antibodies, respectively (Jackson ImmunoResearch, West Grove, PA). Every 12th section through the hippocampus was quantified using optical sectioning by confocal microscopy by an experimenter who was blinded to the genotype. BrdU-positive cells in the hippocampus were counted if they were within the subgranule cell layer, i.e., within one 
cell width or within the granular cell layer of the dentate gyrus. $Z$-plane sectioning ( $1 \mu \mathrm{m}$ steps) was performed to confirm colocalization of BrdU/NeuN double-positive cells. Brain sections from Cre $\times$ Z/EG mice were prepared as above and stained with guinea pig anti-doublecortin (DCX) (Chemicon) or mouse anti-parvalbumin (PAV) (Sigma, St. Louis, MO) followed by a Cy3-conjugated secondary antibody. Quantitation of DCX/green fluorescent protein (GFP)-positive cells in the subgranule cell layer was done as described above for BrdU/NeuN-positive cells. In the subventricular zone, the high DCX staining density was mostly incompatible with counting of individual DCX-positive cell bodies. The percentage of DCX/GFP-positive neuroblast therefore was estimated and extrapolated from subregions of the subventricular zone in which individual DCX-positive cells were less densely packed and could be identified and counted.

Statistical analysis. The criteria for choice of either parametric or nonparametric two-mean comparison tests was a total number of values $(N)$ of 30 (with $N=n 1+n 2$ for two groups) (Snedecor and Cochran, 1989; Conover, 1999). Accordingly, $t$ tests for either pooled (when $n 1=n 2 \pm$ 2) or separate variance (when $n 1$ and $n 2$ were unequal) were chosen for $N \geq 30$. Nonparametric Mann-Whitney tests were used for $N \leq 30$. In the light-dark choice test (see Fig. $4 b$ ), we opted for a $2 \times 2$ genotypearea analysis of variance with area as a within-subject factor because the preference for the dark area varies with the degree of aversion to the lit area. An unweighted solution was used because of inequality of $n 1=9$ and $n 2=22(N=31)$. The investigators conducting the behavioral experiments, autoradiography tests, and immunohistochemical analyses were blinded to the genotype of the animals/tissue.

\section{Results}

The objective of this study was to use the Cre-loxP system to delineate the brain regions and developmental time course underlying heightened anxiety-like behavior described for $\mathrm{GABA}_{\mathrm{A}} \mathrm{R}$ $\gamma 2$ subunit heterozygous mice (global $\gamma 2^{+/-}$mice). Given the selective cognitive deficits in trace fear conditioning and ambiguous cue conditioning of global $\gamma 2^{+/-}$mice, we hypothesized that $\gamma 2$ subunit heterozygosity limited to the forebrain should be sufficient to replicate the anxiety-related behavior described previously (Crestani et al., 1999). Heterozygous deletion of a floxed $\gamma 2$ subunit gene (f $\gamma 2$ ) (Schweizer et al., 2003) directed by two different forebrain-specific and developmentally controlled Cre recombinase transgenes was predicted to result in comparable $\gamma 2$ subunit deficits in adulthood but with marked differences in their onset during development.

\section{Strategy for conditional gene inactivation}

Recombination directed by the EmxlCre gene is first detected at embryonic day 10 and results in recombination of floxed target genes selectively in glutamatergic neurons and glia mainly in neocortex and hippocampus, with low levels of recombination in other regions of the forebrain (Iwasato et al., 2000; Gorski et al., 2002; Iwasato et al., 2004). Notably, Emx1Cre does not induce recombination in GABAergic neurons (Gorski et al., 2002; Iwasato et al., 2004). Emx1Cre-induced inactivation of the $\gamma 2$ subunit gene, which is only expressed in neurons (Laurie et al., 1992a,b; Persohn et al., 1992; Wisden et al., 1992) (supplemental Fig. 1, available at www.jneurosci.org as supplemental material), therefore is expected to lead to a $\mathrm{GABA}_{\mathrm{A}} \mathrm{R}$ deficit selectively in glutamatergic but not GABAergic neurons mainly in the forebrain. Consistent with recombination of the $\mathrm{f} \gamma 2$ locus in the immature brain, mice with Emx1Cre-induced homozygous deletion of the $\gamma 2$ subunit gene (Emx1Cre $\times \mathrm{f} \gamma 2 / \mathrm{f} \gamma 2)$ failed to thrive from the time of birth, developed severe motor deficits, and died in the second postnatal week.

In contrast to embryonic recombination induced by Emx1Cre, recombination induced by the CaMKIICre2834 trans- gene driven by the CaMKII $\alpha$ subunit gene promoter is first detected at P17 (Schweizer et al., 2003). Developmentally delayed recombination is confirmed by the phenotype of CaMKIICre $2834 \times f \gamma 2 / f \gamma 2$ mice, which develop normally to the fourth postnatal week and die with an epilepsy phenotype in the fifth postnatal week [average \pm SEM life expectancy, $30.5 \pm 2.6 \mathrm{~d} ; n=$ 11 (Schweizer et al., 2003)]. Expression of the CaMKII $\alpha$ gene is limited mostly to glutamatergic neurons and absent from GABAergic neurons of the forebrain (Benson et al., 1992; Jones et al., 1994). Therefore, CaMKIICre2834 and Emx1Cre transgenes differ in their developmental recombination patterns but are predicted to ultimately result in comparable $\mathrm{GABA}_{\mathrm{A}} \mathrm{R}$ deficits limited to non-GABAergic forebrain neurons in adulthood. Analyses of the CaMKIICre2834- and Emx1Cre-induced recombination in Z/EG Cre reporter mice (Novak et al., 2000), in which Creinduced recombination can be mapped to individual cells based on the expression of GFP, confirmed the lack of Cre-induced recombination in PAV-positive interneurons in both mouse lines, as expected (Fig. 1).

Changes in the expression of the $\gamma 2$ subunit of $\mathrm{GABA}_{\mathrm{A}} \mathrm{Rs}$ can be assessed in situ by autoradiography of $\mathrm{GABA}_{\mathrm{A}}$ Rs with the $\mathrm{BZ}$ binding site ligand $\left[{ }^{3} \mathrm{H}\right]$ flumazenil (Gunther et al., 1995). Pseudo-wt mice that are homozygous ( $\mathrm{f} \gamma 2 / \mathrm{f} \gamma 2)$ or heterozygous $(\mathrm{f} \gamma 2 /+)$ for the $\mathrm{f} \gamma 2$ locus are indistinguishable from wt with respect to their level of BZ binding sites and the number of $\mathrm{GABA}_{\mathrm{A}}$ Rs at postsynaptic sites (Schweizer et al., 2003), indicating that the $f \gamma 2$ locus is fully functional. To assess the regional deficit in $\mathrm{GABA}_{\mathrm{A}}$ Rs after heterozygous inactivation of the $\mathrm{f} \gamma 2$ locus by the Emx1Cre and CaMKIICre2834 transgenes, respectively, we quantified the density of BZ binding sites in brain sections of 10-week-old mice (Fig. 2). As predicted, we found a very similar reduction in $\left[{ }^{3} \mathrm{H}\right]$ flumazenil binding, regardless of whether recombination of the $\mathrm{f} \gamma 2$ locus was induced in the embryo by Emx1Cre or during adolescence by the CaMKIICre2834 transgene (Fig. $2 a, b)$. In both Emx1Cre $\times \mathrm{f} \gamma 2 /+$ and CaMKIICre $2834 \times \mathrm{f} \gamma 2 /+$ mice, reductions in BZ sites were limited to the forebrain and most pronounced in the striatum (Emx1Cre $\times$ f $\gamma 2 /+,-31.9 \%$; CaMKIICre $2834 \times \mathrm{f} \gamma 2 /+,-25.3 \%$, compared with respective $\mathrm{f} \gamma 2 /+$ littermate controls), hippocampus (CA1) $(-24.8 \%,-26.5 \%)$, and neocortex $(-19.3 \%,-11.4 \%)$, with less of a reduction in the dentate gyrus $(-11.5 \%,-13.5 \%)$ and amygdala $(-13.1 \%,-11.5 \%)$ and no significant deficits in thalamus, globus pallidus, and cerebellum. The comparatively large reduction of $\mathrm{BZ}$ sites in the striatum of both mouse lines was unexpected given the below average reduction of BZ sites $(6 \%)$ in this brain region observed in global $\gamma 2^{+/-}$mice (Crestani et al., 1999) and the low level of recombination induced by Emx1Cre and CaMKIICre2834 in the striatum of reporter strains (Iwasato et al., 2000; Schweizer et al., 2003; Iwasato et al., 2004) (Fig. 1). Nevertheless, Emx1Cre $\times f \gamma 2 /+$ and CaMKIICre $2834 \times f \gamma 2 /+$ mice examined in adulthood showed comparable regional $\mathrm{GABA}_{\mathrm{A}} \mathrm{R}$ deficits, consistent with reduced expression of the $\gamma 2$ subunit in similar subpopulations of neurons.

\section{Mapping the brain substrate of trait anxiety}

To test whether a $\mathrm{GABA}_{\mathrm{A}} \mathrm{R}$ deficit restricted to the Emx1 lineage of neurons is sufficient to induce heightened emotionality, Emx 1 Cre $\times f \gamma 2 /+$ mice and $f \gamma 2 /+$ littermate controls ( 8 weeks of age) were tested for their reactivity to novelty in the free-choice exploration paradigm and to other naturally aversive stimuli in the light-dark choice and elevated plus-maze tests (Crestani et al., 1999). Consistent with normal expression of the $\gamma 2$ subunit from the $f \gamma 2$ locus, the emotional responsiveness of $f \gamma 2 /+$ mice 

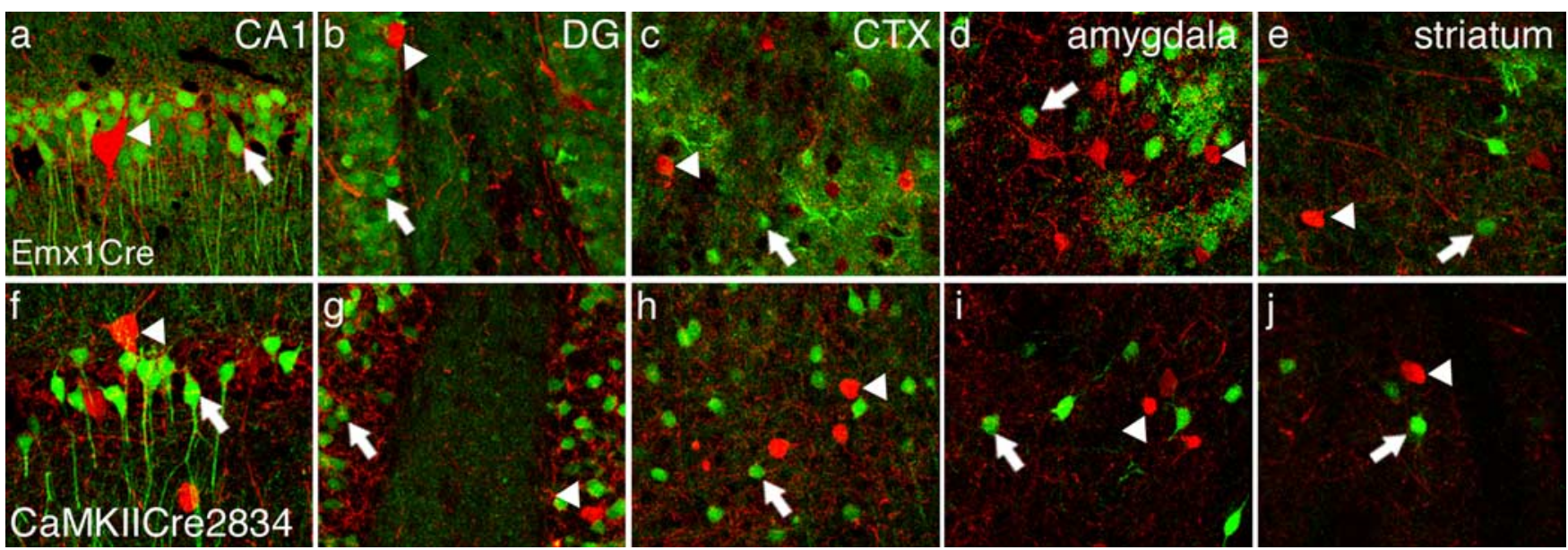

Figure 1. Lack of Cre-induced recombination in PAV-positive interneurons, a major subpopulation of GABAergic interneurons. Brain sections of Emx1Cre $\times$ Z/EG (a- $\boldsymbol{e})$ and CaMKIICre2834 $\times$ Z/EG mice $(\boldsymbol{f}-\boldsymbol{j})$ were stained for PAV and tested for colocalization of PAV (red) and Cre-mediated GFP (green) expression. Representative images are shown for the hippocampal CA1 region $(\boldsymbol{a}, \boldsymbol{f})$, dentate gyrus (DG; $\boldsymbol{b}, \boldsymbol{g})$, neocortex (CTX; $\boldsymbol{c}, \boldsymbol{h})$, amygdala $(\boldsymbol{d}, \boldsymbol{i})$, and striatum $(\boldsymbol{e}, \boldsymbol{j})$. Arrows point to GFP-positive cells that were subject to Cre-induced recombination, and arrowheads point to PAV-positive interneurons. Images represent stacks of confocal images. Note the lack of overlap between PAV-and GFP-positive cell populations. Consistent with published results, GFP-positive cells in Emx 1 Cre $\times$ Z/EG sections suggest recombination in both glia and glutamatergic neurons, whereas Cre-induced expression of GFP in CaMKIICre2834 $\times$ Z/EG brain sections is selective for glutamatergic neurons, as expected.

was indistinguishable from that of wt $\left(\gamma 2^{+/+}\right)$and Emx1Cre mice, as indicated by unchanged behavior in the free-choice exploration and light-dark choice tests (Fig. $3 a-c)$. In contrast, EmxiCre $\times$ f $y 2 /+$ compared with $f y 2 /+$ mice appeared neophobic and displayed greater aversive responses in all three test situations (Fig. $4 a-c$ ). In the free-choice exploration test, Emx1Cre $\times f \gamma 2 /+$ mice made more retractions before entering a novel unit and spent less time in the novel compartment compared with $\mathrm{f} \gamma 2 /+$ controls (Fig. 4a). In the light-dark choice test, the mean time of exposure to the lit area was diminished (Fig. 4b). Likewise, in the elevated plus-maze test, Emx1Cre $\times f \gamma 2 /+$ mice made fewer entries into the open arms compared with controls (Fig. 4c). The lack of genotype-related differences in the mean number of familiar units visited in the free-choice exploration test (Fig. $4 a)$, transitions in the light-dark choice test (Fig. $4 b$ ), and closed arm entries in the elevated plus maze (Fig. $4 c$ ) indicated a retained overall interest for the test situation and unaltered levels of locomotion of Emx1Cre $\times \mathrm{f} \gamma 2 /+$ mice. Thus, a forebrain-specific deficit in $\mathrm{GABA}_{\mathrm{A}}$ Rs that was most pronounced in the striatum, hippocampus (CA1), and neocortex and induced selectively in the Emx1 lineage of cells was sufficient to reproduce the behavioral responses characteristic of trait anxiety seen previously in global $\gamma 2^{+/-}$mice.

At 10 weeks of age, CaMKIICre $2834 \times \mathrm{f} \gamma 2 /+$ mice displayed a regional $\mathrm{GABA}_{\mathrm{A}} \mathrm{R}$ deficit comparable with that of Emx1Cre $\times$ $\mathrm{f} \gamma 2 /+$ mice (Fig. 2). However, in contrast to Emx1Cre $\times f \gamma 2 /+$ mice, recombination induced by CaMKIICre2834 is first detectable at P17 and reaches adult levels only by the fifth postnatal

a

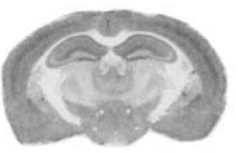

fү2/+

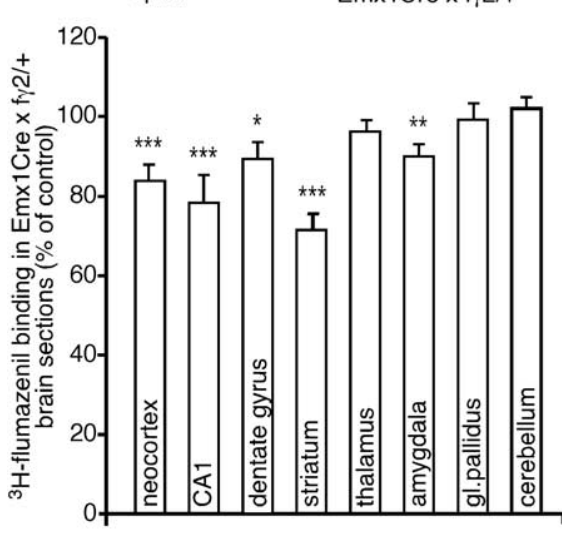

b

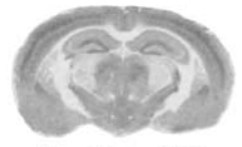

Emx1Cre $\times$ fy2/+

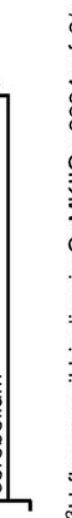

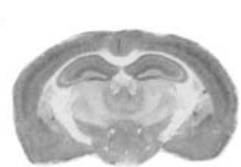

fү2/+

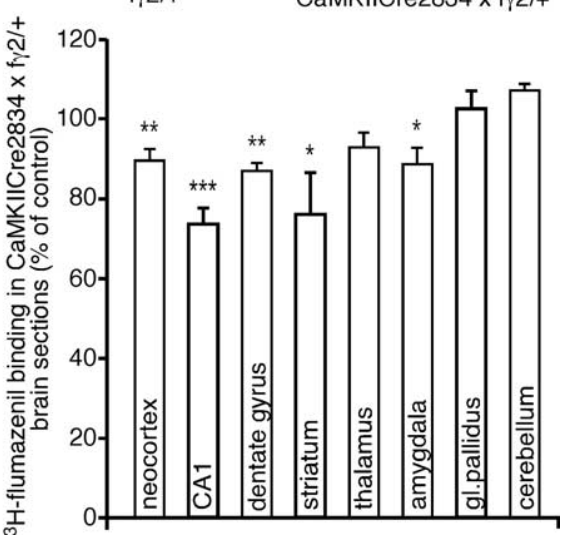

Figure 2. Quantitation of $\mathrm{GABA}_{A} \mathrm{R}$ deficits in Emx1Cre $\times \mathrm{f} \gamma 2 /+$ and CaMKIICre2834 $\times \mathrm{f} \gamma 2 /+$ mice by [ ${ }^{3} \mathrm{H}$ ] flumazenil autoradiography and phosphorimage analysis. a, Representative autoradiographs of brain sections from 10-week-old Emx1Cre $\times f \gamma 2 /+$ mouse and a $f \gamma 2 /+$ littermate control, together with the density of BZ binding sites determined in different brain regions. The density of $\left[{ }^{3} \mathrm{H}\right]$ flumazenil binding sites in brain sections of Emx $1 \mathrm{Cre} \times \mathrm{f} \gamma 2 /+$ was reduced in neocortex, $\mathrm{CA} 1$ region of hippocampus $\left(t_{(38)}=4.6\right.$ and 4.4 , respectively, $t$ test), as well as in dentate gyrus $(U=21)$, striatum $(U=13)$, and amygdala $(U=10)$ (Mann-Whitney test) compared with $f \gamma 2 /+$ controls. The number of $B Z$ sites was unchanged in thalamus, globus pallidus, and cerebellum $(U>26)$. $\boldsymbol{b}$, Representative sections of CaMKIICre $2834 \times f \gamma 2 /+$ and control brains and results of quantitation of [ $\left.{ }^{3} \mathrm{H}\right]$ flumazenil binding sites as in $\boldsymbol{a}$. The density of $\left[{ }^{3} \mathrm{H}\right]$ flumazenil sites in CaMKIICre2834 $\times \mathrm{f} \gamma 2 /+$ mice was reduced in neocortex $\left(t_{(38)}=3.0\right), C A 1\left(t_{(38)}=7.5\right)$, dentate gyrus $(U=19)$, striatum $(U=8.0)$, and amygdala $(U=8.0)$ compared with $\mathrm{f} \gamma 2 /+$ littermate controls. BZ site densities in thalamus, globus pallidus, and cerebellum were unaltered $(U>$ 31). Results represent means $\pm \operatorname{SEM}\left(n=9-20\right.$ per genotype; $\left.{ }^{*} p<0.05,{ }^{* *} p<0.01,{ }^{* * *} p<0.001\right)$.

week (Schweizer et al., 2003). This developmentally delayed deficit in $\mathrm{GABA}_{\mathrm{A}}$ Rs was not associated with an anxiety-like phenotype, as indicated by the absence of a behavioral difference between CaMKIICre $2834 \times f \gamma 2$ mice and $f \gamma 2 /+$ controls analyzed at 8 weeks of age in all three anxiety tests (Fig. $4 d-f$ ).

We wondered whether CaMKIICre $2834 \times \mathrm{f} \gamma 2$ mice failed to exhibit anxiety-like behavioral responses because, at 8 weeks of age, they had been exposed to a $\mathrm{GABA}_{\mathrm{A}} \mathrm{R}$ deficit for a shorter 
a Free choice exploration

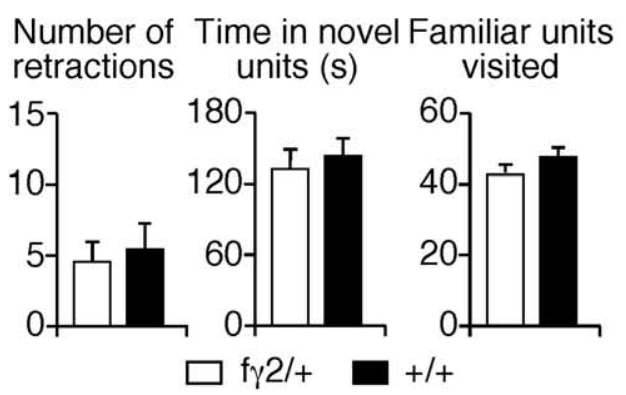

b

Free choice exploration
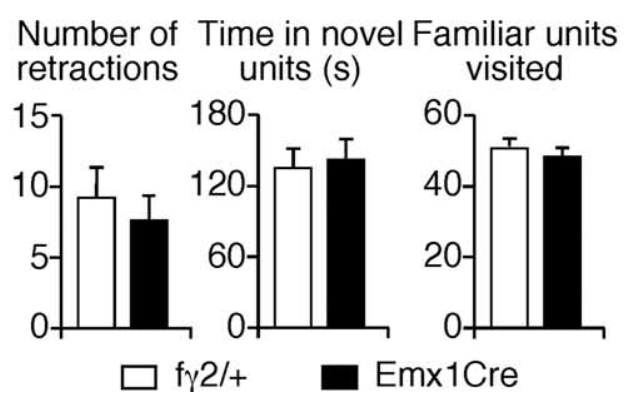

C Light/dark choice

Time in lit Number of
area (s)
transitions

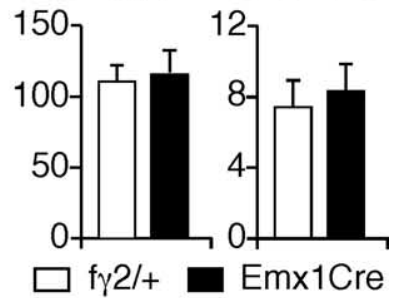

Figure 3. Normal anxiety-related behavior of pseudo-wt mice. $\boldsymbol{a}$, In the free-choice exploration test, $f \gamma 2 /+$ mice were indistinguishable from wt littermates ( $+/+$ ) with respect to the number of retractions from entering a novel unit, the total time spent in the novel units, and the number of familiar units visited (for the three variables, $t_{(36)}<2.00$, Student's $t$ test; $n=19$ per group). $\boldsymbol{b}$, In the same test, Emx1Cre mice were indistinguishable from $f\left(2 /+\right.$ littermates (for the three variables, $t_{(36)}<1.00 ; n=18-20$ ). $c$, In the light- dark choice test, Emx1Cre mice did not differ from $\mathrm{f} \gamma 2 /+$ controls with respect to total time spent in the lit area and the number of light-dark transitions $\left(t_{(37)}<1.00 ; n=19-20\right)$.

period of time than the Emx1Cre $\times f \gamma 2 /+$ mice. To address this possibility, we reassessed the emotionality of CaMKIICre $2834 \times$ $\mathrm{f} \gamma 2 /+$ mice at $4-6$ months of age (Fig. $4 g-i)$. Similar to results at 8 weeks of age, these older CaMKIICre $2834 \times \mathrm{f} \gamma 2 /+$ mice were indistinguishable from littermate $\mathrm{f} \gamma 2 /+$ controls in all three test situations (Fig. $4 g-i$ ). The data suggest that the emotional behavior of CaMKIICre $2834 \times \mathrm{f} \gamma 2 /+$ mice is insensitive to adultspecific $\mathrm{GABA}_{\mathrm{A}} \mathrm{R}$ deficit, even during prolonged exposure to the receptor deficit.

$\mathrm{GABA}_{\mathrm{A}} \mathrm{R}$ deficits promote behavioral inhibition in the forced swim and novelty-suppressed feeding tests

We further analyzed the responsiveness of the different mutant mouse lines in a modified version of the forced swim test, a rodent behavioral assay with appreciable predictive validity for antidepressant drug activity in humans (Lucki, 1997; Dulawa et al., 2004) (Fig. 5). Global $\gamma 2^{+/-}$mice (9 weeks of age) more rapidly developed an immobile posture compared with wt as indicated by the reduced mean time spent swimming until the first immobility episode, and they were more passive as they accumulated more time spent immobile over the duration of the test compared with wt (Fig. 5a). Emx1Cre $\times \mathrm{f} \gamma 2 /+$ mice were indistinguishable from controls with respect to time spent to first immobility but accumulated more time in an immobile posture than controls, similar to global $\gamma 2^{+/-}$mice (Fig. $5 b$ ). In contrast, CaMKIICre $2834 \times \mathrm{f} \gamma 2 /+$ mice behaved indistinguishably from $\mathrm{f} \gamma 2 /+$ littermate controls (Fig. $5 c$ ). The same mice were also tested in the novelty-suppressed feeding paradigm, which assesses an inhibitory response that is reduced by chronic but not acute antidepressant drug treatment (Suranyi-Cadotte et al., 1990; Santarelli et al., 2003). Both global $\gamma 2^{+/-}$and Emx1Cre $\times f \gamma 2 /+$ mice exhibited a longer delay in initiating feeding when forced into a novel environment than the respective control mice, whereas CaMKIICre2834 $\times \mathrm{f} \gamma 2 /+$ mice did not differ from controls (Fig. $5 d-f$ ). The data indicate that a global or Emxl cell lineage-specific $\mathrm{GABA}_{\mathrm{A}} \mathrm{R}$ deficit that is present throughout development, but not a comparable $\mathrm{GABA}_{\mathrm{A}} \mathrm{R}$ deficit induced in brain of adolescent mice, leads to greater behavioral inhibition in response to stress.

\section{Subtle $\mathrm{GABA}_{\mathrm{A}} \mathrm{R}$ deficits affect adult neurogenesis}

Recent evidence indicates that GABAergic transmission controls the proliferation of neural progenitor cells and the integration of immature neurons into established neural networks (Liu et al., 2005; Tozuka et al., 2005; Ge et al., 2006). To examine the consequences of $\gamma 2$ subunit deficits on adult neurogenesis, we sub- jected 8-week-old mice to metabolic labeling with the DNA synthesis marker BrdU and, 4 weeks later, quantified BrdU-positive and BrdU/NeuN double-positive neurons in the subgranular layer of the dentate gyrus (Fig. $6 a$ ). NeuN is a nuclear pan-neural marker expressed selectively in mature neurons. In $\gamma 2^{+/-}$mice, the total number of BrdU-positive cells $(532.8 \pm 111.1)$ did not differ from that of wt mice ( $604 \pm 103.3 ; n=5$ per genotype; $U=$ 11 ; NS). In contrast, the number of neurons that were double positive for BrdU and $\mathrm{NeuN}$ was significantly reduced $(-45.1 \%)$ in $\gamma 2^{+/-}$compared with wt mice $\left(\gamma 2^{+/-}, 218.4 \pm 34.0\right.$; wt, $398.0 \pm 65.6 ; U=3.5 ; p<0.05$ ) (Fig. 6b), suggesting a deficit in the differentiation, maturation, and/or survival of adult-born hippocampal neurons. Emx1Cre $\times \mathrm{f} \gamma 2 /+$ mice showed a deficit in BrdU/NeuN double-positive cells $(-41.5 \%)$ that was virtually identical to that of global $\gamma 2^{+/-}$mice $($EmxlCre $\times \mathrm{f} \gamma 2 /+$, $223.2 \pm 51.7 ; \mathrm{f} \gamma 2 /+, 381.6 \pm 18.7 ; n=5$ per genotype; $U=2.0$; $p<0.05$ ) (Fig. 6c). In contrast, the dentate gyrus of CaMKIICre $2834 \times f \gamma 2 /+$ mice was not different from littermate $\mathrm{f} \gamma 2 /+$ controls with respect to both the numbers of BrdU-positive cells $($ CaMKIICre2834 × f $\gamma 2 /+, 926.4 \pm 50.7 ; \mathrm{f} \gamma 2 /+, 816.0 \pm 60.7)$ and BrdU/NeuN-positive neurons (CaMKIICre2834 $\times \mathrm{f} \gamma 2 /+$, $487.2 \pm 43.7 ; \mathrm{f} \gamma 2 /+, 494.4 \pm 25.0 ; n=5$ per genotype; $U<12.5$; NS) (Fig. 6d). The data suggest that the $\mathrm{GABA}_{\mathrm{A}} \mathrm{R}$ deficit associated with $\gamma 2$ subunit heterozygosity results in reduced differentiation, maturation, and/or survival of adult-born subgranule cell layer neurons but only if this $\mathrm{GABA}_{\mathrm{A}} \mathrm{R}$ deficit extends to the immature neurons.

Emx1Cre $\times f y 2 /+$ and $\gamma 2^{+/-}$mice showed no significant change in the number of BrdU-positive cells. However, the mean values measured 4 weeks after labeling invariably tended to be lower compared with controls (Fig. $6 b, c$ and data not shown), probably reflecting reduced survival of neurons. Alternatively, we wondered whether this tendency might reflect a small effect of $\mathrm{GABA}_{\mathrm{A}} \mathrm{R}$ deficits on replication of adult-born cells. To more directly and accurately quantify the number of proliferation of replicating cells in $\gamma 2^{+/-}$and wt littermates, we injected the mice with a single large dose of BrdU and harvested the brains $24 \mathrm{~h}$ later. Unaltered numbers of BrdU-labeled cells in the subgranule cell layer of the dentate gyrus of $\gamma 2^{+/-}(1704 \pm 94.9)$ compared with wt mice ( $1848 \pm 125.0 ; n=5$ per genotype; $U=9.5$; NS) (Fig. 6e) confirmed that cell proliferation was unaffected by heterozygosity of the $\gamma 2$ subunit. Reduced neurogenesis observed in $\gamma 2^{+/-}$and Emx1Cre $\times \mathrm{f} \gamma 2 /+$ mice therefore was caused selectively by impaired differentiation, maturation, or survival of immature neurons. 
The deficits in adult neurogenesis observed in global $\gamma 2^{+/-}$and Emx1Cre $\times$ $\mathrm{f} \gamma 2 /+$ mice might reflect altered network activity or reduced $\mathrm{GABA}_{\mathrm{A}} \mathrm{R}$ function specifically in neural progenitor cells and immature neurons. To address whether Emx1Cre $\times \mathrm{f} \gamma 2 /+$ and CaMKIICre $2834 \times$ f $\gamma 2 /+$ mice might differ with respect to possible $\mathrm{GABA}_{\mathrm{A}} \mathrm{R}$ deficits in adult-born neurons, we compared the Emx1Cre- and CaMKIICre2834-induced recombination pattern in adult-born immature neurons of 6-week-old Cretransgenic Z/EG reporter mice (Novak et al., 2000). Cre-mediated recombination in these mice results in expression of GFP, allowing the mapping of Cre-mediated recombination with cellular resolution. Immature GFP-positive neurons were identified by immunofluorescent staining for DCX, a neural cell lineage-specific intermediate filament protein that is transiently expressed during the first 3-4 weeks after the last cell division of neural progenitor cells (Brown et al., 2003). Interestingly, in the dentate gyrus of 6-week-old Emx1Cre $\times$ Z/EG mice, the majority (74.6 $\pm 2.0 \% ; n=3$ mice) of DCXpositive neuroblasts were positive for GFP, indicating that they had undergone Cremediated recombination (Fig. $\left.7 a-a^{\prime \prime}\right)$. In contrast, virtually no recombination was evident in DCX-positive neuroblast in the dentate gyrus of CaMKIICre $2834 \times \mathrm{Z} / \mathrm{EG}$ mice $(2.1 \pm 1.6 \% ; n=3)$ (Fig. $\left.7 b-b^{\prime \prime}\right)$.

We similarly compared Emx1Cre- and CaMKIICre2834-mediated recombination in the subventricular/periventricular zone of the lateral ventricles, which, with its projection through the rostral migratory stream, is next to the dentate gyrus, the only other neurogenic brain region known to be active in adulthood. Unlike in the subgranule cell layer, semiquantitative analysis of the subventricular zone of 6-week-old Emx1Cre $\times \mathrm{Z} / \mathrm{EG}$ mice revealed that only $7.4 \pm 0.5 \%$ ( $n=3$ brains $)$ of DCX-positive neuroblasts had undergone Cre-mediated recombination, and no recombination was detected in neuroblasts from the subventricular zone of CaMKIICre2834 × Z/EG mice (Fig. 7c-e).

Abundant GFP-positive/DCX-negative cells in the subventricular zone of Emx1Cre $\times \mathrm{Z} / \mathrm{EG}$ mice by and large exhibit non-neural morphology and most likely represent different glial cell types (Gorski et al., 2002). This is in keeping with the notion that neuroblasts originating in the subventricular zone give rise mainly to granule and glomerular inhibitory neurons of the olfactory bulb (for review, see Lledo et al., 2006; Ge et al., 2007) and that Emx1Cre-mediated recombination is restricted to non-GABAergic neurons and glia (Gorski et al., 2002; Iwasato et al., 2004) (Fig. 1). The data suggest that the $\mathrm{GABA}_{\mathrm{A}} \mathrm{R}$ deficit of Emx1Cre $\times f \gamma 2 /+$ mice in addition to mature glutama-
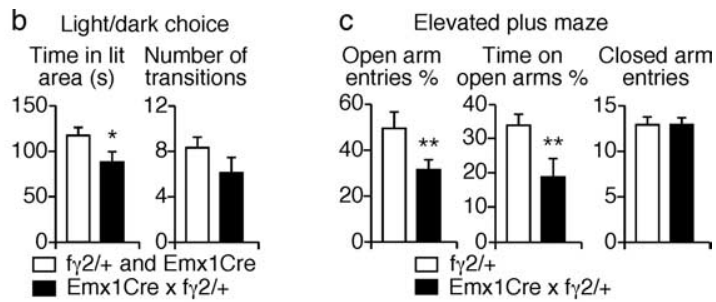

\section{d Free choice exploration}

Number of Time in novel Familiar units retractions units (s) visited

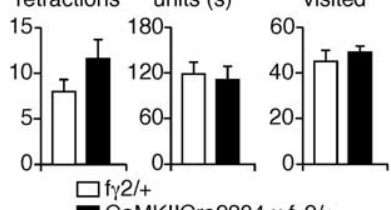

e Light/dark choice Time in lit Number of area (s) transitions

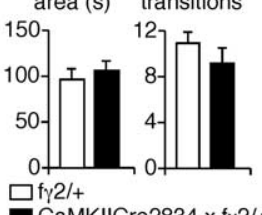

f Elevated plus maze

Open arm Time on Closed arm

entries $\%$ open arms $\%$ entries

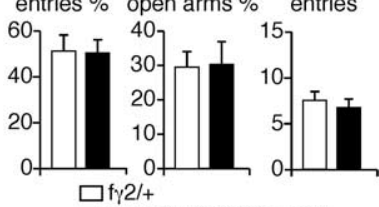

CaMKIICre2834 x fy2/+

- CaMKIICre2834 x fy2/+

Number of Time in novel Familiar units retractions units (s) visited

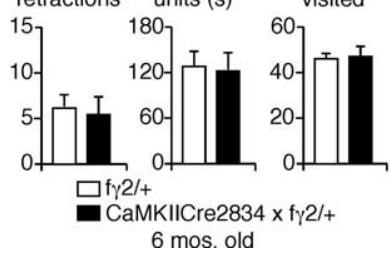

h Light/dark choice Time in lit Number of area (s) transitions

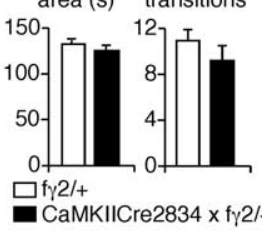
4 mos. old

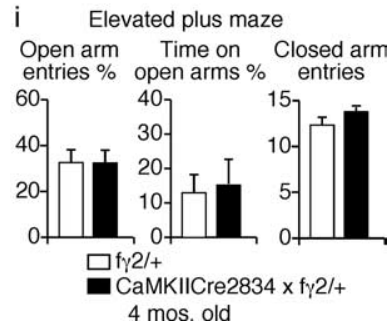

Figure 4. $\mathrm{GABA}_{\mathrm{A}} \mathrm{Rs}$ act during development to control trait anxiety. $\boldsymbol{a}-\boldsymbol{c}$, Heightened anxiety-related behavior of Emx1Cre $\times$ $\mathrm{f} \gamma 2 /+$ mice. In the free-choice exploration test $(\boldsymbol{a})$, Emx1Cre $\times \mathrm{f} \gamma 2 /+$ mice made more retractions from entering a novel unit after the removal of the partition ( $U=10.5 ; p<0.01 ; n=8-10$ per genotype), and, once they entered, they spent less time in the novel compartment $(U=8 ; p<0.01)$ than $f \gamma 2 /+$ littermate controls. The mean number of familiar units visited was similar in the two groups $(U=28.5$; NS). In the light-dark choice test $(\boldsymbol{b})$, the mean time spent in the lit area was significantly lower in Emx1Cre $\times \mathrm{f} \gamma 2 /+(n=9)$ than in $\mathrm{f} \gamma 2 /+$ littermate control mice $(n=22)(p<0.05$, least significant difference test after unweighted mean genotype $\times$ area ANOVA with area as within-subject factor, $\left.F_{(1,29)}=4.0 ; p=0.05\right)$. The group difference was not significant for the mean number of light-dark transitions $\left(t_{(13.17)}=1.8 ; p<0.1, t\right.$ test with separate variances). In the elevated plus maze $(\boldsymbol{c})$, the mean proportion of both entries and time spent on the open arms over 5 min were decreased in Emx1Cre $\times f \gamma 2 /+$ compared with littermate control mice $(U=19.5$ and 20 , respectively; $p<0.01 ; n=10-14$ per genotype). $\boldsymbol{d}-\boldsymbol{f}$, The anxiety-related behavior of CaMKIICre2834 $\times f \gamma 2 /+$ mice and littermate $f \gamma 2 /+$ controls was tested under the same conditions. In the free-choice exploration test (d), CaMKIICre2834 $\times f \gamma 2 /+$ mice behaved as controls with respect to mean number of retractions $\left(t_{(36.99)}=1.5 ; n=22-30\right.$ per genotype) and mean time spent in the novel compartment $\left(t_{(45.58)}=0.3\right)$. In the light-dark choice test (e), CaMKIICre2834 $\times \mathrm{f} \gamma 2 /+$ mice were indistinguishable from controls for the mean time spent in the lit area and the mean number of light-dark transitions $(U>34 ; n=10$ per genotype). In the elevated plus maze $(\boldsymbol{f})$, CaMKIICre2834 $\times f \gamma 2 /+$ mice did not differ from controls with respect to the mean proportion of entries and time spent on the open arms and the number of closed arm entries $\left(t_{(34)} \leq 0.7 ; n=18\right.$ per genotype). All experiments were performed with females reared in group-housed cages. Data are representative of two to four experiments each. Values shown represent group means \pm SEM. $\boldsymbol{g}-\boldsymbol{i}$, The anxiety-related behavior of 4- to 6-month-old CaMKIICre2834 $\times f(\gamma 2 /+$ mice was assessed as in $\boldsymbol{d}-\boldsymbol{f}$. In the free-choice exploration test $(\boldsymbol{g}), 6$-month-old CaMKIICre2834 $\times f \gamma 2 /+$ were indistinguishable from $f \gamma 2 /+$ littermate controls with respect to the number of retractions from entering a novel unit, the total time spent in the novel units, and the number of CaMKIICre2834 $\times f \gamma 2 /+$ mice $(n=7)$ assessed at 4 months of age, mice did not differ from $f \gamma 2 /+(n=21)$ with respect to both the total time spent in the lit area and the number of light- dark transitions $(U>45)$. Similarly, behavior in the elevated plus maze (i) of 4-month-old CaMKIICre2834 $\times \mathrm{f} \gamma 2 /+$ mice $(n=7)$ was indistinguishable from $\mathrm{f} \gamma 2 /+$ littermates $(n=21)$ with respect to the number of open and closed arm entries and time spent on the open arms $(U>38)$. Data represent means \pm SEM.

tergic neurons extends to the majority of adult-born immature granule cells in the dentate gyrus and a comparatively minor fraction of so far ill-defined neuroblasts in the subventricular zone.

In summary, deficits in neurogenesis, trait anxiety, and behavioral inhibition of $\gamma 2$ subunit heterozygous mice have in common that their manifestation is dependent on the same developmental $\mathrm{GABA}_{\mathrm{A}} \mathrm{R}$ deficit. In addition to the deficit in mature glutamatergic neurons, which by itself is without neurogenic and behavioral consequences, the causal $\mathrm{GABA}_{\mathrm{A}} \mathrm{R}$ deficit extends to 

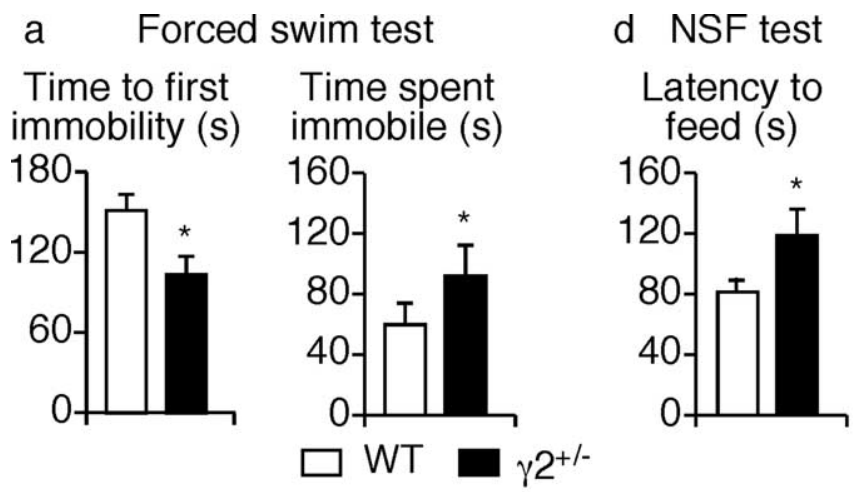

b Forced swim test

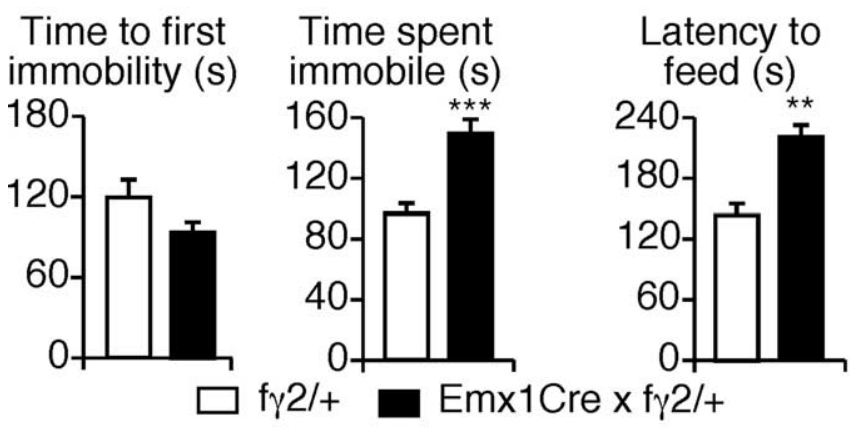

c Forced swim test

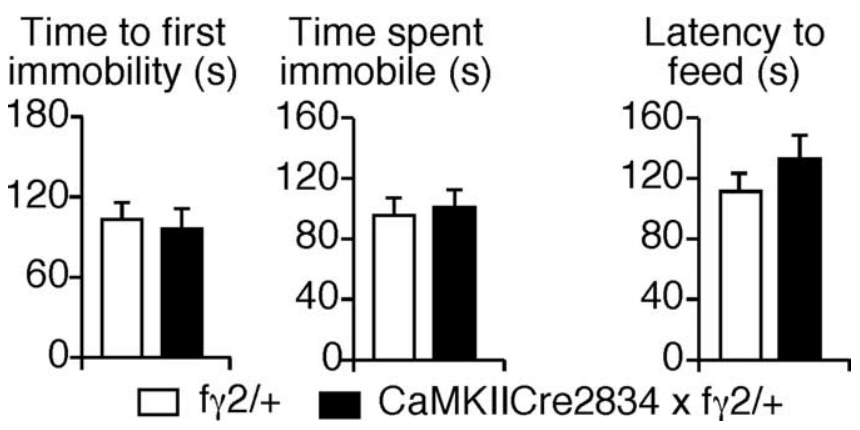

Figure 5. A developmental deficit in $\gamma 2$ subunit-containing $G A B A_{A} R s$ results in greater inhibition in two behavioral assays sensitive to antidepressant drug treatment. The three different mouse lines $\left(\gamma 2^{+/-}\right.$, Emx1Cre $\times f \gamma 2 /+$, and CaMKIICre2834 $\left.\times f \gamma 2 /+\right)$ together with their respective littermate controls (wt and $f \gamma 2 /+$ mice, respectively) were subjected to the modified forced swim (Lucki, 1997) (a-c) and novelty-suppressed feeding (Santarelli et al., 2003) (d-f) tests. $\boldsymbol{a}$, In the forced swim test, $\gamma 2^{+/-}$mice started floating significantly earlier and spent more time immobile than wt controls $(U=13.0$ and 20.0 , respectively; $p<0.05$; $n=9$ per genotype). $\boldsymbol{b}$, Tested under the same conditions, Emx1Cre $\times \mathrm{f} \gamma 2 /+$ mice did not differ significantly from $f \gamma 2 /+$ with respect to mean time to first immobility $(U=26)$ but exhibited an increase in the mean time spent immobile compared with controls $(U=2.5 ; n=$ $6-14 ; p<0.001)$. c, CaMKIICre2834 $\times \mathrm{f} \gamma 2 /+$ mice were indistinguishable from $\mathrm{f} \gamma 2 /+$ littermates for both parameters. $\boldsymbol{d}$, In the novelty-suppressed feeding test, $\gamma 2^{+/-}$mice showed a heightened mean latency to initiate feeding compared with wt $(U=19 ; p<0.05$; $n=9$ per genotype). $\boldsymbol{e}$, Likewise, the mean latency to initiate feeding was significantly increased in Emx1Cre $\times f \gamma 2 /+$ compared with controls $(U=3.0 ; n=6-14 ; p<0.001)$. $f$, In the novelty-suppressed feeding test, CaMKIICre2834 $\times \mathrm{f} \gamma 2 /+$ mice were indistinguishable from $f \gamma 2 /+$ littermate controls ( $U>33 ; n=8-12$ per genotype). Values represent group means \pm SEM.

adult-born neuroblasts of the dentate gyrus and some neuroblasts generated in the subventricular zone of the neocortex. Possible mechanistic links between $\mathrm{GABA}_{\mathrm{A}} \mathrm{R}$ deficits in immature neurons, reduced neurogenesis, and altered behavior are discussed.

\section{Discussion \\ GABAergic developmental control of trait anxiety and behavioral inhibition}

Cell type-specific and developmentally controlled gene deletion was used to elucidate the molecular and cellular substrate underlying trait anxiety associated with a modest $\mathrm{GABA}_{\mathrm{A}} \mathrm{R}$ deficit. Heterozygous deletion of the $\gamma 2$ subunit induced selectively in developing forebrain glutamatergic neurons (Emx1Cre $\times \mathrm{f} \gamma 2 /+$ mice) reproduced the behavioral features of global $\gamma 2^{+/-}$mice (Crestani et al., 1999). In addition, global $\gamma 2^{+1-}$ and Emx1Cre $\times$ $\mathrm{f} \gamma 2 /+$ mice exhibited marked behavioral inhibition in two stressful test situations known to predict antidepressant drug efficacy in humans. Both the immobility behavior of mice in the forced swim test and the susceptibility to mood disorders in humans have been mapped previously to a $\mathrm{GABA}_{\mathrm{A}} \mathrm{R}$ gene cluster that includes the $\gamma 2$ subunit gene (Yoshikawa et al., 2002; Yamada et al., 2003). Importantly, a comparable $\mathrm{GABA}_{\mathrm{A}} \mathrm{R}$ deficit of CaMKIICre $2834 \times \mathrm{f} \gamma 2$ mice that was delayed to adolescence and limited to mature glutamatergic neurons lacked behavioral consequences.

The presence of $\mathrm{GABA}_{\mathrm{A}} \mathrm{R}$ deficit during development and in adult-born neurons results in trait anxiety and behavioral inhibition

The observation that altered behavior of $\gamma 2^{+/-}$mice may depend specifically on $\mathrm{GABA}_{\mathrm{A}} \mathrm{R}$ deficits during development is reminiscent of abundant evidence that vulnerability to anxiety and mood disorders in humans may have a developmental origin (Chorpita and Barlow, 1998; Bremne and Vermetten, 2001; McEwen, 2003; Gross and Hen, 2004). Alternatively or in addition to a simple developmental mechanism, altered behavior of EmxlCre $\times$ $\mathrm{f} \gamma 2 /+$ mice may reflect cell type-specific differences in the $\mathrm{GABA}_{\mathrm{A}} \mathrm{R}$ deficit observed in adulthood. In particular, Cre-mediated recombination of floxed target genes by Emx1Cre but not CaMKIICre2834 extends to adult-born immature neurons in the hippocampus and, to a lesser extent, in the periventricular area of the forebrain, the two regions of the mammalian brain known to continue production of new neurons throughout adulthood.

Reduced $\mathrm{GABA}_{\mathrm{A}} \mathrm{R}$ function during development and in immature neurons leads to selective deficits in adult neurogenesis

Subtle functional deficits in $\gamma 2$-containing $\mathrm{GABA}_{\mathrm{A}}$ Rs result in a marked reduction in adult hippocampal neurogenesis. This observation is consistent with recent electrophysiological and pharmacological evidence demonstrating that GABAergic input via $\mathrm{GABA}_{\mathrm{A}}$ Rs controls the proliferation, maturation, and synaptic integration of adult-born neurons, thereby setting the pace for activity-dependent postnatal neurogenesis (Liu et al., 2005; Tozuka et al., 2005; Ge et al., 2006; Karten et al., 2006) (for review, see Ge et al., 2007). The proliferation of neural progenitors in the hippocampus of adult $\gamma 2^{+/-}$mice was unaltered, indicating that reduced formation of mature neurons reflected reduced maturation, differentiation, and/or survival of adult-born neurons. This finding is consistent with the essential role of the $\gamma 2$ subunit in postsynaptic clustering of $\mathrm{GABA}_{\mathrm{A}} \mathrm{Rs}$, a prerequisite for the formation of functional GABAergic synapses and normal GABAergic innervation (Essrich et al., 1998; Li et al., 2005; Fang et al., 2006). Notably, the $\gamma 2$ subunit is dispensable for neurogenesis in the embryonic brain as indicated by the normal size and cortical lamination of brains of newborn $\gamma 2^{-1-}$ mice (Gunther et al., 1995), although the $\gamma 2$ mRNA is normally highly expressed already at embryonic day 15 (Laurie et al., 1992b), around the time 

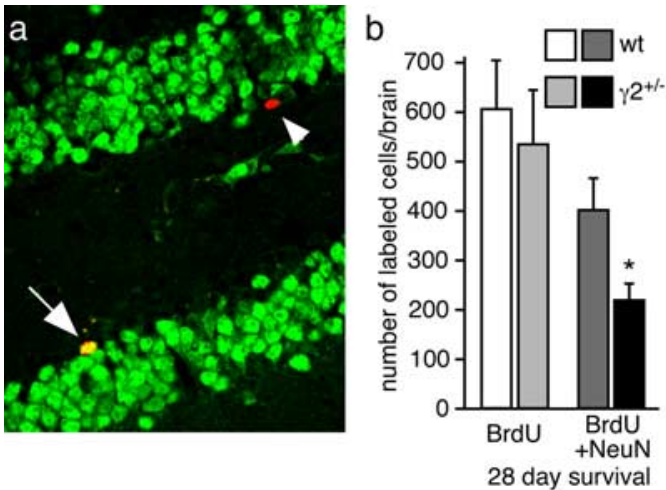
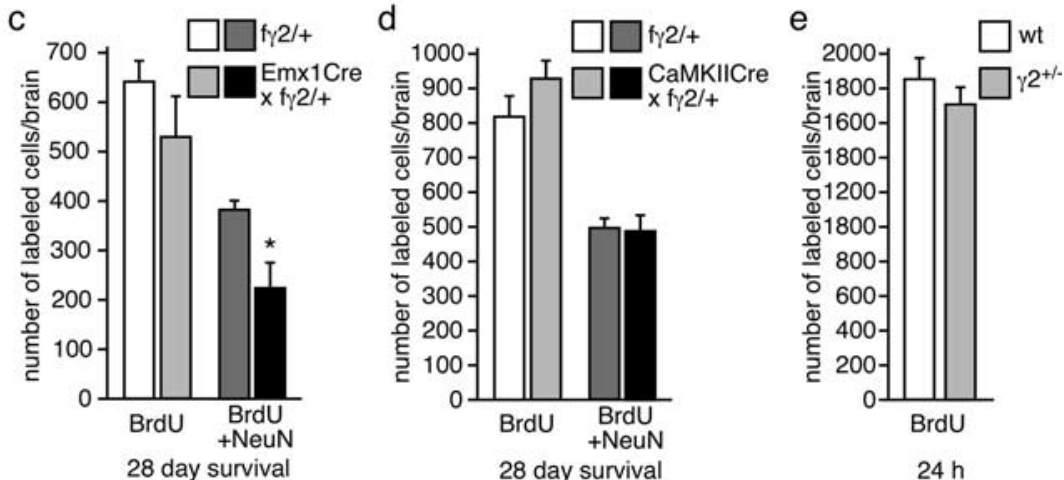

Figure 6. A developmental but not adult deficit in $\gamma 2$ subunit-containing $G_{A B A} A_{A}$ ss leads to a reduction in adult-born hippocampal neurons. $\boldsymbol{a}-\boldsymbol{d}$, Hippocampal brain sections of mice labeled at 8 weeks of age and harvested 4 weeks later were stained using antibodies specific for BrdU (red) and the pan-neural marker NeuN (green). $\boldsymbol{a}$, A representative confocal image of a section through the dentate gyrus shows a BrdU-positive neuron (arrow) and an adult-born non-neural cell (arrowhead). Quantitation of total BrdU-positive cells and BrdU/NeuN double-positive neurons in the subgranule and granule cell layer of serial hippocampal sections of $\gamma 2^{+/-}(\boldsymbol{b})$, Emx1Cre x f $\gamma 2 /+(\boldsymbol{c})$, and CaMKIICre2834 $\times f \gamma 2 /+$ mice $(\boldsymbol{d})$ compared with littermate controls $(n=5-6$ mice per genotype in each experiment) revealed a profound reduction in BrdU/NeuN double-positive neurons relative to littermate controls in $\gamma 2^{+-}(54.9 \pm 8.5 \%$ of wt; $U=3.5 ; p<0.05)$ and Emx1Cre $\times f \gamma 2 /+$ mice $(58.5 \pm 13.5 \%$ of $f \gamma 2 /+; U=2.0 ; p<0.05)$, which suffer from a $G_{A B A} R$ deficit throughout brain development. In contrast, the proportion of adult-born neurons in the hippocampus of CaMKIIICre2834 $\times \mathrm{f} \gamma 2$ mice was not different from that of littermate controls $(U=12.0$; NS). The number of total BrdU-positive cells did not differ significantly from controls in any of the mutant mouse lines analyzed $\left(\gamma 2^{+/-}, 88.2 \pm 18.4 \%\right.$ of $w t ;$ Emx1Cre $\times f \gamma 2 /+, 82.4 \pm 12.8 \%$ of $f \gamma 2 /+$ and CaMKIIICre $2834 \times f \gamma 2 /+, 113.5 \pm 6.2 \%$ of $f \gamma 2 /+; U>6.5$ for all three groups). $\boldsymbol{e}$, The number of proliferating cells in the subgranule cell layer of mice labeled with BrdU $24 \mathrm{~h}$ before harvesting of brains was not different in $\gamma 2^{+/-}$compared with wt mice $\left(\gamma 2^{+/-}\right.$, $92.2 \pm 5.1 \%$ of wt; $n=5$ per genotype; $U=9.5 ; \mathrm{NS}$ ). Data indicate means \pm SEM.

when the majority of neocortical neurons become postmitotic (Caviness et al., 1995). The function of nonsynaptic $\gamma 2$ subunitcontaining $\mathrm{GABA}_{\mathrm{A}} \mathrm{Rs}$ therefore is much less dependent on the $\gamma 2$ subunit than the function of postsynaptic $\mathrm{GABA}_{\mathrm{A}} \mathrm{Rs}$ (Gunther et al., 1995; Baer et al., 1999) (for review, see Luscher and Keller, $2004)$. Modestly reduced expression of the $\gamma 2$ subunit, as seen in $\gamma 2^{+/-}$mice (Crestani et al., 1999), therefore is predicted to affect mainly or exclusively synaptic GABAergic transmission.

Dentate gyrus granule cells are among the very few neural cell types that are produced throughout adulthood, and they are functionally unique in many ways. Compared with their embryonic counterparts, they may be especially vulnerable to $\gamma 2$ subunit deficits as a result of their prolonged period of maturation, integration into neural networks, and synaptogenesis, processes that depend on a gradual rise of the intracellular chloride concentration and a transition from slow nonsynaptic GABAergic excitation to fast synaptic GABAergic inhibition (Overstreet Wadiche et al., 2005, 2006; Ge et al., 2006). Unlike pyramidal neurons, which contain $\alpha 2 \beta \gamma 2$ subunit-containing $\mathrm{GABA}_{\mathrm{A}} \mathrm{Rs}$ on dendrites, soma, and axon initial segment, granule cells contain similar or perhaps identical $\mathrm{GABA}_{\mathrm{A}}$ Rs also at mossy fiber terminals (Bergersen et al., 2003). GABAergic input via these receptors has been proposed to modulate action potential-dependent neurotransmitter release of mossy fiber terminals onto CA3 pyramidal cells (Ruiz et al., 2003; Nakamura et al., 2007). Behaviorally, mossy fiber-CA3 synapses are believed to hold a gatekeeper function for information flow from the dentate gyrus to the CA3-CA1 region of the hippocampus and to play a role in the memory of sequences of events (Nakazawa et al., 2003). GABA ${ }_{\mathrm{A}} \mathrm{R}$-deficient mossy fiber-CA3 synapses might explain facilitated trace conditioning of $\gamma 2^{+/-}$mice (Crestani et al., 1999). However, it remains to be seen whether mossy fiber-CA3 synapses are indeed functionally impaired in $\gamma 2^{+/-}$mice.

\section{Are deficits in neurogenesis causal for heightened emotionality?}

Altered behavioral inhibition of $\gamma 2$-deficient mice appears to be correlated with the reduced rate of adult neurogenesis because the two phenotypes depend on the same $\mathrm{GABA}_{\mathrm{A}} \mathrm{R}$ deficit ob- served in global $\gamma 2^{+/-}$and Emx1Cre $\mathrm{x} f \gamma 2 /+$ mice but absent in CaMKIICre $2834 \times$ f $\gamma 2 /+$ mice. The $\mathrm{GABA}_{\mathrm{A}} \mathrm{R}$ deficit of CaMKIICre2834 $\times$ f $\gamma 2 /+$ mice was comparable in magnitude and regional distribution to that of Emx1Cre $\times \mathrm{f} \gamma 2 /+$ mice but limited to mature neurons that had already completed GABAergic synapse formation (Schweizer et al., 2003).

Deficits in neurogenesis have been implicated in the etiology of mood disorders based on the neurogenesis-promoting effect of diverse antidepressant therapies, the detrimental effect of stress on neurogenesis, and the hippocampal atrophy that is notable in depressed patients (Duman, 2004; Mirescu and Gould, 2006). Our results raise the question whether deficits in adult neurogenesis might be causal for the emotional, behavioral, and cognitive changes observed in Emx1Cre $\times \mathrm{f} \gamma 2 /+$ and/or $\gamma 2^{+/-}$mice. In addition to our study, evidence in support of a functional link between neurogenesis and anxiety-related behavior comes from studies in rodents showing that early life stress induced in pups by maternal deprivation results in reduced expression of $\mathrm{GABA}_{\mathrm{A}} \mathrm{Rs}$ and increased anxiety-related behavior in adulthood (Caldji et al., 2000, 2003, 2004), as well as reduced neurogenesis (Mirescu et al., 2004). However, unlike in $\gamma 2^{+/-}$and Emx1Cre $\times f \gamma 2 /+$ mice, the inhibitory effect of stress on neurogenesis is attributable to reduced proliferation rather than impaired maturation, survival, or differentiation of adult-born neurons (Karten et al., 2005). Nevertheless, the evidence presented here suggests that early life stress-induced deficits in $\mathrm{GABA}_{\mathrm{A}} \mathrm{Rs}$ are not merely an inconsequential side effect of stress but instead may represent an important step in a succession of events that link early life stress to heightened anxiety and emotional behavior and deficits in neurogenesis in adulthood. Conversely, genetic and environmental factors, such as early life stress, that are implicated in the development of anxiety, depression, and impaired adult neurogenesis might have in common that they involve deficits in GABAergic transmission.

Despite this evidence in support of a mechanistic link between reduced neurogenesis and enhanced emotionality, there is other experimental evidence suggesting that impaired neurogenesis alone is insufficient to alter emotional behavior. For example, deficits in proliferation of neural progenitors induced in adult 

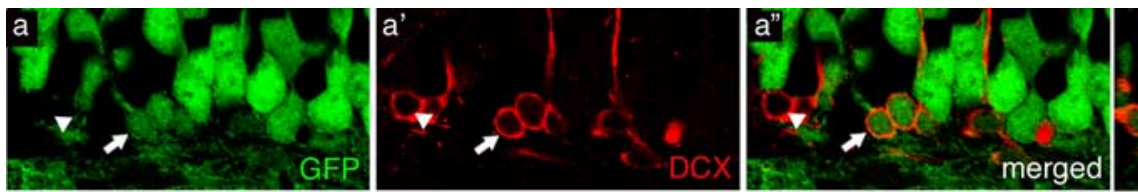

Emx1Cre $\times$ Z/EG
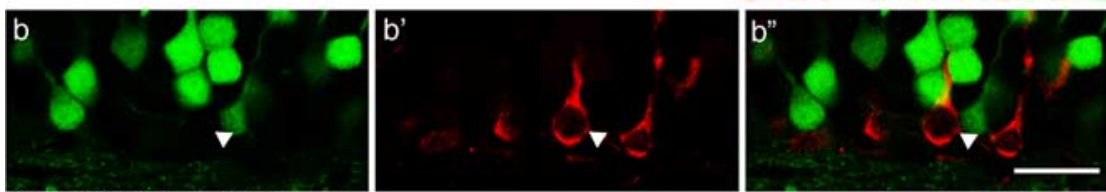

CaMKIICre2834 x Z/EG
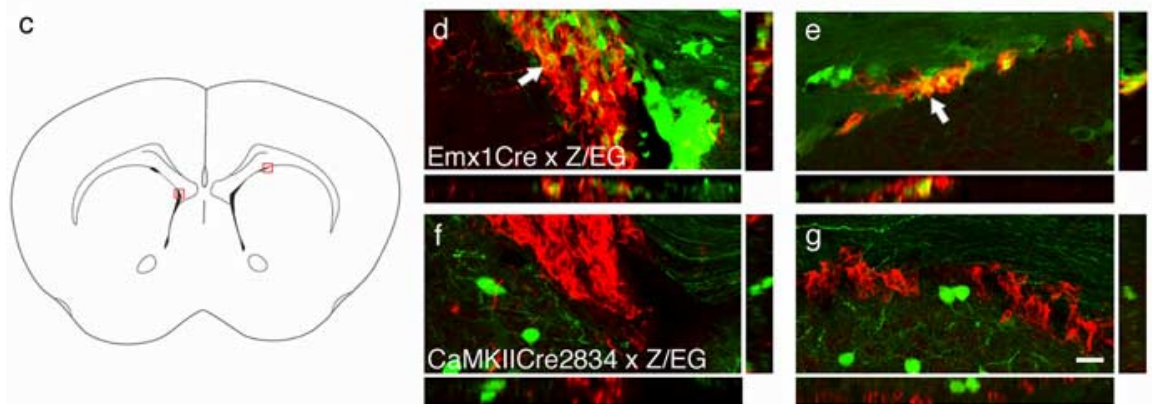

Figure 7. Differential Emx1Cre and CaMKIICre2834-mediated recombination in immature neurons of the subgranular and subventricular zones. Coronal brain sections of 6-week-0ld Emx1Cre $\times$ Z/EG $\left(\boldsymbol{a}-\boldsymbol{a}^{\prime \prime}, \boldsymbol{d}, \boldsymbol{e}\right)$ and CaMKIICre2834 $\times$ Z/EG mice $\left(\boldsymbol{b}-\boldsymbol{b}^{\prime \prime}\right.$, $\boldsymbol{f}, \boldsymbol{g})$ through the hippocampus $\left(\boldsymbol{a}-\boldsymbol{a}^{\prime \prime}, \boldsymbol{b}-\boldsymbol{b}^{\prime \prime}\right)$ or lateral ventricles $(\boldsymbol{d}-\mathbf{g})$ were stained with antibody for DCX (red) and analyzed for colocalization with Cre-induced GFP (green) by confocal microscopy. c, Schematic drawing indicating the location (red squares) of medial $(\boldsymbol{d}, \boldsymbol{f})$ and dorsal $(\boldsymbol{e}, \boldsymbol{g})$ sections of the periventricular zone. Note the efficient recombination in immature (DCX-positive, arrows) granule cells in the subgranule cell layer of Emx1Cre $\times$ Z/EG mice $\left(\boldsymbol{a}-\boldsymbol{a}^{\prime \prime}\right)$, whereas DCX-positive cells in corresponding sections of CaMKIICre2834 × Z/EG mice lack GFP ( $\boldsymbol{b}$ - $\boldsymbol{b}^{\prime \prime}$, arrowheads). Similarly, DCX/GFP double-positive neurons were evident in the subventricular zone of Emx1Cre $\times$ Z/EG mice (d, $\boldsymbol{e}$, arrows) but absent in corresponding sections of CaMKIICre2834 $\times$ Z/EG mice $(\boldsymbol{f}, \boldsymbol{g})$. Merged green and red images $\left(\boldsymbol{a}^{\prime \prime}, \boldsymbol{b}^{\prime \prime}, \boldsymbol{d}-\boldsymbol{g}\right)$ include orthogonal views of $x-z$ and $y-z$ planes to confirm colocalization of GFP and DCX in sections of Emx1Cre $\times$ Z/EG mice. GFP-positive cells are more abundant in Emx1Cre $\times$ Z/EG than CaMKIICre2834 $\times$ Z/EG mice, consistent with Cre-mediated recombination extending to glia in Emx1Cre $\times$ Z/EG but not in CaMKIICre2834 $\times$ Z/EG mice. Scale bars, $20 \mu \mathrm{m}$.

rats by drug-induced serotonergic denervation or serotonin depletion are insufficient to alter emotional behavior (Henn and Vollmayr, 2004; Rosenbrock et al., 2005; Ueda et al., 2005). However, given the generally low fraction of adult-generated neurons that survive to maturity even in control animals, it is unclear whether reduced proliferation of progenitors in these studies has resulted in reduced production of adult-born mature neurons.

\section{Limitations of the present study}

A limitation inherent to the design of our study is that it relies on comparison of two principally unrelated mouse lines $($ Emx1Cre $2834 \times f \gamma 2 /+$ and CaMKIICre $2834 \times f \gamma 2 /+)$. These mice exhibit striking differences in cell type-specific recombination of the $\gamma 2$ gene in immature neurons, which we propose to be responsible for the behavioral and neurogenic deficits observed. However, we cannot conclusively exclude additional differences between these two mouse lines that could potentially contribute to the different behavioral outcomes. In addition to its prominent role in neurogenesis, GABAergic transmission is also known to regulate neural migration and neurite outgrowth of immature neurons (Represa and Ben-Ari, 2005). However, all these mechanisms depend on nonsynaptic paracrine-like function of GABA and, as discussed above, are unlikely to be affected significantly in $\gamma 2^{+/-}$mice.

In conclusion, $\gamma 2^{+/-}$mice represent an animal model of heightened negative emotionality, a personality trait common to GAD and depression in humans (Gamez et al., 2006), induced by subtle developmental deficits in $\mathrm{GABA}_{\mathrm{A}} \mathrm{Rs}$ and associated with reduced adult neurogenesis. Future experiments will have to address whether the conclusions presented here hold up also in mouse models with $\mathrm{GABA}_{\mathrm{A}}$ Rs deficits that are restricted to immature neurons of the postnatal or adult brain. Moreover, additional validation of the $\gamma 2^{+/-}$mouse model will require demonstration that the relevant behaviors are responsive to antidepressant drug treatment.

\section{References}

Baer K, Essrich C, Benson JA, Benke D, Bluethmann H, Fritschy J-M, Luscher B (1999) Postsynaptic clustering of $\mathrm{GABA}_{\mathrm{A}}$ receptors by the $\gamma 3$ subunit in vivo. Proc Natl Acad Sci USA 96:12860-12865.

Benson DL, Isackson PJ, Gall CM, Jones EG (1992) Contrasting patterns in the localization of glutamic acid decarboxylase and $\mathrm{Ca}^{2+}$ / calmodulin protein kinase gene expression in the rat central nervous system. Neuroscience 46:825-849.

Bergersen L, Ruiz A, Bjaalie JG, Kullmann DM, Gundersen V (2003) GABA and $\mathrm{GABA}_{\mathrm{A}}$ receptors at hippocampal mossy fibre synapses. Eur J Neurosci 18:931-941.

Brambilla P, Perez J, Barale F, Schettini G, Soares JC (2003) GABAergic dysfunction in mood disorders. Mol Psychiatry 8:721-737, 715.

Bremne JD, Vermetten E (2001) Stress and development: behavioral and biological consequences. Dev Psychopathol 13:473-489.

Brown JP, Couillard-Despres S, Cooper-Kuhn CM, Winkler J, Aigner L, Kuhn HG (2003) Transient expression of doublecortin during adult neurogenesis. J Comp Neurol 467:1-10.

Caldji C, Francis D, Sharma S, Plotsky PM, Meaney MJ (2000) The effects of early rearing environment on the development of $\mathrm{GABA}_{\mathrm{A}}$ and central benzodiazepine receptor levels and novelty-induced fearfulness in the rat. Neuropsychopharmacology 22:219-229.

Caldji C, Diorio J, Meaney MJ (2003) Variations in maternal care alter GABA(A) receptor subunit expression in brain regions associated with fear. Neuropsychopharmacology 28:1950-1959.

Caldji C, Diorio J, Anisman H, Meaney MJ (2004) Maternal behavior regulates benzodiazepine/GABA $\mathrm{A}_{\mathrm{A}}$ receptor subunit expression in brain regions associated with fear in BALB/c and C57BL/6 mice. Neuropsychopharmacology 29:1344-1352.

Caviness Jr VS, Takahashi T, Nowakowski RS (1995) Numbers, time and neocortical neuronogenesis: a general developmental and evolutionary model. Trends Neurosci 18:379-383.

Chambers JA, Power KG, Durham RC (2004) The relationship between trait vulnerability and anxiety and depressive diagnoses at long-term follow-up of Generalized Anxiety Disorder. J Anxiety Disord 18:587-607.

Chorpita BF, Barlow DH (1998) The development of anxiety: the role of control in the early environment. Psychol Bull 124:3-21.

Conover WJ (1999) Practical nonparametric statistics, Ed 3. New York: Wiley.

Crestani F, Lorez M, Baer K, Essrich C, Benke D, Laurent JP, Belzung C, Fritschy JM, Luscher B, Mohler H (1999) Decreased GABA $A_{A}$-receptor clustering results in enhanced anxiety and a bias for threat cues. Nat Neurosci 2:833-839.

Dulawa SC, Holick KA, Gundersen B, Hen R (2004) Effects of chronic fluoxetine in animal models of anxiety and depression. Neuropsychopharmacology 29:1321-1330.

Duman RS (2004) Depression: a case of neuronal life and death? Biol Psychiatry 56:140-145.

Essrich C, Lorez M, Benson J, Fritschy J-M, Luscher B (1998) Postsynaptic 
clustering of major $\mathrm{GABA}_{\mathrm{A}}$ receptor subtypes requires the gamma2 subunit and gephyrin. Nat Neurosci 1:563-571.

Fang C, Deng L, Keller CA, Fukata M, Fukata Y, Chen G, Luscher B (2006) GODZ-mediated palmitoylation of $\mathrm{GABA}_{\mathrm{A}}$ receptors is required for normal assembly and function of GABAergic inhibitory synapses. J Neurosci 26:12758-12768.

Gamez W, Watson D, Doebbeling BN (2006) Abnormal personality and the mood and anxiety disorders: implications for structural models of anxiety and depression. J Anxiety Disord, in press.

Ge S, Goh EL, Sailor KA, Kitabatake Y, Ming GL, Song H (2006) GABA regulates synaptic integration of newly generated neurons in the adult brain. Nature 439:589-593.

Ge S, Pradhan DA, Ming Gl, Song H (2007) GABA sets the tempo for activity-dependent adult neurogenesis. Trends Neurosci 30:1-8.

Glue P, Wilson S, Coupland N, Ball D, Nutt D (1995) The relationship between benzodiazepine receptor sensitivity and neuroticism. J Anxiety Disord 9:33-45.

Gorski JA, Talley T, Qiu M, Puelles L, Rubenstein JL, Jones KR (2002) Cortical excitatory neurons and glia, but not GABAergic neurons, are produced in the Emx1-expressing lineage. J Neurosci 22:6309-6314.

Gross C, Hen R (2004) The developmental origins of anxiety. Nat Rev Neurosci 5:545-552.

Gunther U, Benson J, Benke D, Fritschy J-M, Reyes G, Knoflach F, Crestani F, Aguzzi A, Arigoni M, Lang Y, Bluethmann H, Mohler H, Luscher B (1995) Benzodiazepine-insensitive mice generated by targeted disruption of the $\gamma 2$ subunit gene of $\mathrm{GABA}_{\mathrm{A}}$ receptors. Proc Natl Acad Sci USA 92:7749-7753.

Henn FA, Vollmayr B (2004) Neurogenesis and depression: etiology or epiphenomenon? Biol Psychiatry 56:146-150.

Iwasato T, Datwani A, Wolf AM, Nishiyama H, Taguchi Y, Tonegawa S, Knopfel T, Erzurumlu RS, Itohara S (2000) Cortex-restricted disruption of NMDAR1 impairs neuronal patterns in the barrel cortex. Nature 406:726-731.

Iwasato T, Nomura R, Ando R, Ikeda T, Tanaka M, Itohara S (2004) Dorsal telencephalon-specific expression of Cre recombinase in PAC transgenic mice. Genesis 38:130-138.

Jones EG, Huntley GW, Benson DL (1994) Alpha calcium/calmodulindependent protein kinase II selectively expressed in a subpopulation of excitatory neurons in monkey sensory-motor cortex: comparison with GAD-67 expression. J Neurosci 14:611-629.

Kaplan EM, DuPont RL (2005) Benzodiazepines and anxiety disorders: a review for the practicing physician. Curr Med Res Opin 21:941-950.

Karten YJ, Olariu A, Cameron HA (2005) Stress in early life inhibits neurogenesis in adulthood. Trends Neurosci 28:171-172.

Karten YJ, Jones MA, Jeurling SI, Cameron HA (2006) GABAergic signaling in young granule cells in the adult rat and mouse dentate gyrus. Hippocampus 16:312-320.

Laurie DJ, Seeburg PH, Wisden W (1992a) The distribution of $13 \mathrm{GABA}_{\mathrm{A}}$ receptor subunit mRNAs in the rat brain. II. Olfactory bulb and cerebellum. J Neurosci 12:1063-1076.

Laurie DJ, Wisden W, Seeburg PH (1992b) The distribution of thirteen $\mathrm{GABA}_{\mathrm{A}}$ receptor subunit mRNAs in the rat brain. III. Embryonic and postnatal development. J Neurosci 12:4151-4172.

Li RW, Yu W, Christie S, Miralles CP, Bai J, Loturco JJ, De Blas AL (2005) Disruption of postsynaptic GABA receptor clusters leads to decreased GABAergic innervation of pyramidal neurons. J Neurochem 95:756-770.

Lister RG (1990) Ethologically-based animal models of anxiety disorders. Pharmacol Ther 46:321-340.

Liu X, Wang Q, Haydar TF, Bordey A (2005) Nonsynaptic GABA signaling in postnatal subventricular zone controls proliferation of GFAPexpressing progenitors. Nat Neurosci 8:1179-1187.

Lledo PM, Alonso M, Grubb MS (2006) Adult neurogenesis and functional plasticity in neuronal circuits. Nat Rev Neurosci 7:179-193.

Lorez M, Benke D, Luscher B, Mohler H, Benson JA (2000) Single-channel properties of neuronal $\mathrm{GABA}_{\mathrm{A}}$-receptors lacking the $\gamma 2$ subunit. J Physiol (Lond) 527:11-31.

Lucki I (1997) The forced swimming test as a model for core and component behavioral effects of antidepressant drugs. Behav Pharmacol 8:523-532.

Luscher B, Keller CA (2004) Regulation of $\mathrm{GABA}_{\mathrm{A}}$ receptor trafficking and channel activity in functional plasticity of inhibitory synapses. Pharmacol Ther 102:195-221.
McEwen BS (2003) Early life influences on life-long patterns of behavior and health. Ment Retard Dev Disabil Res Rev 9:149-154.

McNaughton N (1999) A gene promotes anxiety in mice-and also in scientists. Nat Med 5:1131-1132.

Mirescu C, Gould E (2006) Stress and adult neurogenesis. Hippocampus 16:233-238.

Mirescu C, Peters JD, Gould E (2004) Early life experience alters response of adult neurogenesis to stress. Nat Neurosci 7:841-846.

Mohler H, Fritschy JM, Rudolph U (2002) A new benzodiazepine pharmacology. J Pharmacol Exp Ther 300:2-8.

Nakamura M, Sekino Y, Manabe T (2007) GABAergic interneurons facilitate mossy fiber excitability in the developing hippocampus. J Neurosci 27:1365-1373.

Nakazawa K, Sun LD, Quirk MC, Rondi-Reig L, Wilson MA, Tonegawa S (2003) Hippocampal CA3 NMDA receptors are crucial for memory acquisition of one-time experience. Neuron 38:305-315.

Novak A, Guo C, Yang W, Nagy A, Lobe CG (2000) Z/EG, a double reporter mouse line that expresses enhanced green fluorescent protein upon Cremediated excision. Genesis 28:147-155.

O'Boyte CA, Harris D, Barry H, Cullen JH (1986) Differential effect of benzodiazepine sedation in high and low anxious patients in a "real life" stress setting. Psychopharmacology 88:226-229.

Overstreet Wadiche L, Bromberg DA, Bensen AL, Westbrook GL (2005) GABAergic signaling to newborn neurons in dentate gyrus. J Neurophysiol 94:4528-4532.

Overstreet-Wadiche LS, Bensen AL, Westbrook GL (2006) Delayed development of adult-generated granule cells in dentate gyrus. J Neurosci 26:2326-2334

Persohn E, Malherbe P, Richards JG (1992) Comparative molecular neuroanatomy of cloned GABAA receptor subunits in the rat CNS. J Comp Neurol 326:193-216.

Represa A, Ben-Ari Y (2005) Trophic actions of GABA on neuronal development. Trends Neurosci 28:278-283.

Rosenbrock H, Bloching A, Weiss C, Borsini F (2005) Partial serotonergic denervation decreases progenitor cell proliferation in the adult rat hippocampus, but has no effect on rat behavior in the forced swimming test. Pharmacol Biochem Behav 80:549-556.

Ruiz A, Fabian-Fine R, Scott R, Walker MC, Rusakov DA, Kullmann DM (2003) GABAA receptors at hippocampal mossy fibers. Neuron 39:961-973.

Santarelli L, Saxe M, Gross C, Surget A, Battaglia F, Dulawa S, Weisstaub N, Lee J, Duman R, Arancio O, Belzung C, Hen R (2003) Requirement of hippocampal neurogenesis for the behavioral effects of antidepressants. Science 301:805-809.

Schweizer C, Balsiger S, Bluethmann H, Mansuy M, Fritschy JM, Mohler H, Luscher B (2003) The $\gamma 2$ subunit of $\mathrm{GABA}_{\mathrm{A}}$ receptors is required for maintenance of receptors at mature synapses. Mol Cell Neurosci 24:442-450.

Snedecor GW, Cochran WG (1989) Statistical methods, Ed 8. Ames, IA: Iowa State UP.

Suranyi-Cadotte BE, Bodnoff SR, Welner SA (1990) Antidepressant-anxiolytic interactions: involvement of the benzodiazepine-GABA and serotonin systems. Prog Neuropsychopharmacol Biol Psychiatry 14:633-654.

Tozuka Y, Fukuda S, Namba T, Seki T, Hisatsune T (2005) GABAergic excitation promotes neuronal differentiation in adult hippocampal progenitor cells. Neuron 47:803-815.

Tunnicliff G, Malatynska E (2003) Central GABAergic systems and depressive illness. Neurochem Res 28:965-976.

Ueda S, Sakakibara S, Yoshimoto K (2005) Effect of long-lasting serotonin depletion on environmental enrichment-induced neurogenesis in adult rat hippocampus and spatial learning. Neuroscience 135:395-402.

Wisden W, Laurie DJ, Monyer H, Seeburg PH (1992) The distribution of 13 $\mathrm{GABA}_{\mathrm{A}}$ receptor subunit mRNAs in the rat brain. I. Telencephalon, diencephalon, mesencephalon. J Neurosci 12:1040-1062.

Yamada K, Watanabe A, Iwayama-Shigeno Y, Yoshikawa T (2003) Evidence of association between gamma-aminobutyric acid type A receptor genes located on $5 \mathrm{q} 34$ and female patients with mood disorders. Neurosci Lett 349:9-12.

Yoshikawa T, Watanabe A, Ishitsuka Y, Nakaya A, Nakatani N (2002) Identification of multiple genetic loci linked to the propensity for "behavioral despair” in mice. Genome Res 12:357-366. 